\title{
Human impact on the transport of terrigenous and anthropogenic elements to peri-alpine lakes (Switzerland) over the last decades
}

\author{
Florian Thevenon - Stefanie B. Wirth • \\ Marian Fujak · John Poté · Stéphanie Girardclos
}

Received: 22 August 2012/Accepted: 6 February 2013/Published online: 22 February 2013

(C) The Author(s) 2013. This article is published with open access at Springerlink.com

\begin{abstract}
Terrigenous ( $\mathrm{Sc}, \mathrm{Fe}, \mathrm{K}, \mathrm{Mg}, \mathrm{Al}, \mathrm{Ti}$ ) and anthropogenic $(\mathrm{Pb}$ and $\mathrm{Cu})$ element fluxes were measured in a new sediment core from Lake Biel (Switzerland) and in previously well-documented cores from two upstream lakes (Lake Brienz and Lake Thun). These three large perialpine lakes are connected by the Aare River, which is the main tributary to the High Rhine River. Major and trace element analysis of the sediment cores by inductively coupled plasma mass spectrometry (ICP-MS) shows that the site of Lake Brienz receives three times more terrigenous elements than the two other studied sites, given by the role of Lake Brienz as the first major sediment sink located in the foothills of the Alps. Overall, the terrigenous fluxes reconstructed at the three studied sites suggest that the construction of sediment-trapping reservoirs during the twentieth century noticeably decreased the riverine
\end{abstract}

Electronic supplementary material The online version of this article (doi:10.1007/s00027-013-0287-6) contains supplementary material, which is available to authorized users.

F. Thevenon $(\bowtie) \cdot J$. Poté

Institute F.-A. Forel, University of Geneva, Versoix, Switzerland

e-mail: florian.thevenon@yahoo.fr

S. B. Wirth

Geological Institute, ETH Zürich, Zürich, Switzerland

M. Fujak

Eawag, Swiss Federal Institute of Aquatic Science and

Technology, Dübendorf, Switzerland

S. Girardclos

Institut des Sciences de l'Environnement, University of Geneva,

Carouge, Switzerland

S. Girardclos

Dept of Geology and Paleontology, University of Geneva,

Geneva, Switzerland suspended sediment load at a regional scale. In fact, the extensive river damming that occurred in the upstream watershed catchment (between ca. 1930 and 1950 and up to 2,300 $\mathrm{m}$ a.s.1.) and that significantly modified seasonal suspended sediment loads and riverine water discharge patterns to downstream lakes noticeably diminished the long-range transport of (fine) terrigenous particles by the Aare River. Concerning the transport of anthropogenic pollutants, the lowest lead enrichment factors (EFs $\mathrm{Pb}$ ) were measured in the upstream course of the Aare River at the site of Lake Brienz, whereas the metal pollution was highest in downstream Lake Biel, with the maximum values measured between 1940 and 1970 (EF $\mathrm{Pb}>3$ ). The following recorded regional reduction in aquatic $\mathrm{Pb}$ pollution started about 15 years before the actual introduction of unleaded gasoline in 1985. Furthermore, the radiometric dating of the sediment core from Lake Biel identifies three events of hydrological transport of artificial radionuclides released by the nuclear reactor of Mühleberg located at more than $15 \mathrm{~km}$ upstream of Lake Biel for the time period 1970-2000.

Keywords Lake sediment - Terrigenous flux ·

Trace metals · Radionuclides · Human impact

\section{Introduction}

The high denudation rate (the sum of chemical weathering and physical erosion) affecting the European Alps (up to $0.9 \pm 0.3 \mathrm{~mm} /$ year in the Swiss Central Alps) is due to a high relief, a steep topography and a high crustal thickness (Wittmann et al. 2007). The resulting particle transport is particularly elevated in peri-alpine rivers with glacial catchments, and the suspended particles primarily accumulate on 
the bottom of peri-alpine lakes, which have been acting as sediment trap for upstream sediment erosion since the deglaciation from the last glacial maximum (Bezinge et al. 1989; Hinderer 2001; Wessels 1998; Ivy-Ochs et al. 2004). The quantification of sediment transport and terrigenous fluxes at a river-basin scale therefore allows a better understanding of biogeochemical cycles at a regional scale (Gaillardet et al. 1999; Millot et al. 2003; Pokrovsky et al. 2010). In addition, the analysis of the terrigenous particles transported to peri-alpine lakes using sediment cores provides an excellent opportunity for reconstructing the impacts of past climate changes on the natural environment (Arnaud et al. 2005; Chapron et al. 2005; Girardclos et al. 2005). However, little attention has been paid so far to the superimposed anthropogenic influence, which substantially altered the suspended sediment load of the main alpine rivers during the last decades, principally due to particle retention in large reservoirs located behind hydropower dams (Loizeau and Dominik 2000; Syvitski et al. 2005; Wetter et al. 2011). In fact, the riverine sediment transport in the European Alps, which is primarily controlled by environmental factors (climate, vegetation cover and topography) influencing the rate and process of weathering, has been significantly altered by the extensive construction of reservoirs and hydroelectric dams that drastically changed hydrological patterns and reduced suspended sediment loads (Vörösmarty et al. 2003; Finger et al. 2006; Thevenon et al. 2012). Therefore, attempts at understanding present-day riverine discharge patterns based on river-borne sediment material, or the reconstruction of past climate and runoff variations based on the accumulation of lacustrine sediments, should be applied with caution due to possible human impact on the terrestrial elemental fluxes at the scale of the drainage basin (Walling et al. 1998; Yang et al. 2005; Wüest et al. 2007).

The studied system of the three lakes (Lake Brienz, Lake Thun and Lake Biel) connected by one major river (Aare River; Fig. 1) provides an excellent opportunity to evaluate the impact of anthropogenic changes on element fluxes through time. Indeed, the numerous hydropower dams constructed upstream of Lake Brienz in the highalpine Grimsel area (up to 2,300 m a.s.1; Fig. 1) have strikingly altered the seasonality of the river flow (shift of the particle input from summer to winter) and have considerably reduced the overall particle input from upstream glaciers to Lake Brienz (Wüest et al. 2007). In addition to these hydropower operations, the Aare River, which is the main water supplier of the High Rhine River, was redirected into Lake Biel in 1878 and has been regulated by the Hagneck hydroelectric dam since 1900, in an effort to prevent flooding of the nearby area called "Seeland" (Fig. 1). Finally, precipitation and stream-flow discharge have been monitored for about 100 years in this region (FOEN 2010; MeteoSwiss 2012) and therefore offer a comprehensive dataset to compare historical climate and human-induced hydrological changes with the reconstructed changes in terrigenous sediment transport to perialpine lakes.

The quantification of trace elements continuously accumulating in the sediments at the bottoms of peri-alpine lakes can be used to evaluate the modern pollution level as well as to assess the temporal evolution of the water pollution and its relation with (past) human activities (Thevenon et al. 2011a; Thevenon and Poté 2012). Indeed, the enrichment of trace metals in lacustrine sedimentary archives gives access to the history of anthropogenic pollutant input, and provides the possibility to evaluate the recent metal contamination in comparison to the natural (or pre-historic) level (Eades et al. 2002; Thevenon et al. 2011b). In the absence of long-term environmental records that could provide pre-anthropogenic levels of pollutants (i.e. natural background levels), the enrichment of trace metals can be expressed relative to the lowest values in the record, which are generally found in the oldest sections of the analysed sediment records (Shotyk et al. 1998; Arnaud et al. 2004; Thevenon et al. 2011b).

As a prerequisite of such a sediment-based environmental reconstruction, well-dated sediment records are demanded. Additionally to historical events, activity profiles of ${ }^{137} \mathrm{Cs}$ and ${ }^{210} \mathrm{~Pb}$ radionuclides provide a valuable dating tool for the 20th century and thus allow for the calculation of element fluxes and the comparison of sediment records from different sites. Such a radiocesium profile of sediment cores from Lake Biel (Switzerland, Fig. 1) revealed anomalous ${ }^{137} \mathrm{Cs}$ peaks dated to 1977 and 1982 that were caused by radionuclide discharges from the upstream Mühleberg Nuclear Power Plant (NPP) (Albrecht et al. 1998). The contamination of fluvial waters by liquid releases from Swiss and French nuclear installations and the long-term retention of long-lived radionuclides have also been evidenced in surface and overbank sediments from some of the major European rivers (e.g. Rhine, Rhône and Moselle Rivers) (Mundschenk 1992, 1996; Provansal et al. 2012; Ferrand et al. 2012). However, despite major concerns for human health and the environment, continuous and well-dated sedimentary records reconstructing the historical deposition of anthropogenic radionuclides released by the nuclear industry are still scarce.

\section{Materials and methods}

\section{Study sites}

The basic parameters of the tree studied lakes are summarized in Table 1 and described in the presentation of the lakes below. 
Fig. 1 Map of the studied area presenting the old and new courses of the Kander and Aare rivers, the location of the dams mentioned in the text (marked by black rectangles), the location of the sediment cores (indicated by red dots) retrieved from Lake Biel (BIE10-3; this study), Brienz (BR03-10; Anselmetti et al. 2007) and Thun (THU07-06; Wirth et al. 2011), as well as the location of the Mühleberg nuclear power plant and the gauging stations (grey dots) mentioned in the text. Upper right insert Map of Switzerland indicating mean annual precipitation

(1961-1990; MeteoSwiss 2012), the studied area (white dashed square) and the catchment area of Lake Biel (non-shaded area)

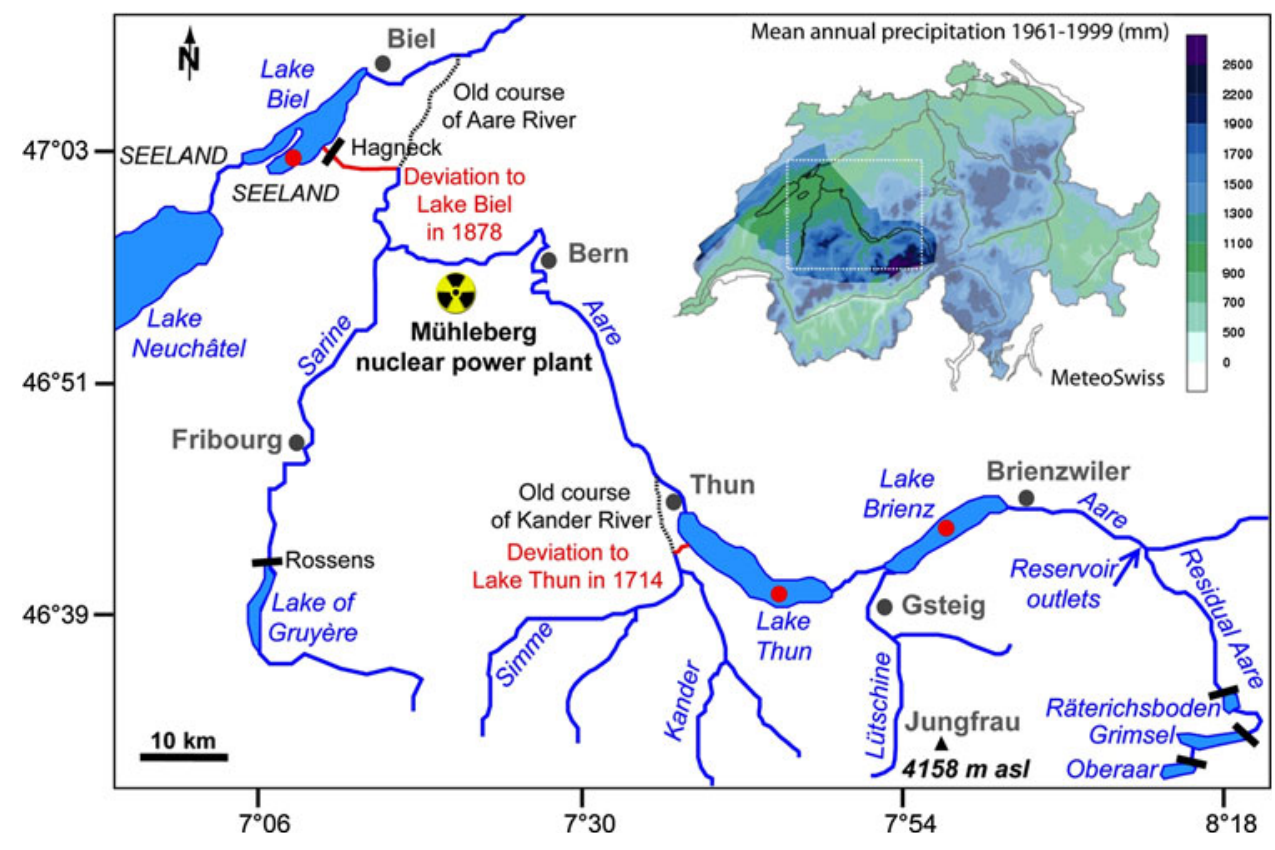

\section{Lake Brienz}

Lake Brienz lies at an altitude of $566 \mathrm{~m}$ a.s.l. in a frontal range valley of the Swiss Alps. The Lake Brienz catchment area covers $1,140 \mathrm{~km}^{2}$ and is situated in a partially glaciated ( $\sim 19 \%$ of total area) mountainous environment with $50 \%$ of its surface lying above $2,000 \mathrm{~m}$ a.s.l. The lake has a surface area of $29.8 \mathrm{~km}^{2}$, a volume of $5.17 \mathrm{~km}^{3}$ and a maximum depth of $261 \mathrm{~m}$. It is holomictic and ultra-oligotrophic with almost exclusively allochthonous clastic input. The water residence time is 2.7 years (Liechti 1994).

The Aare and the Lütschine rivers are the major water and sediment suppliers to Lake Brienz. Although the discharge of the heavily dammed Aare River (gauging station in Brienzwiler) is still nearly twice as high as that of the Lütschine River (not dammed; gauging station in Gsteig) (Figs. 1, 4), the annual sediment loads are almost equal in both rivers. However, the annual particle input to the uppermost part of the lake's water column is dominated by material from the Aare River (92.8 kt/year compared with $64.7 \mathrm{kt} /$ year from the Lütschine River) (Finger et al. 2006). The total annual sediment input into Lake Brienz lies in the range of 250-350 kt (average $302 \mathrm{kt}$ ) and has decreased by approximately $232 \mathrm{kt} / \mathrm{year}$ due to sedimentation in the reservoirs Grimselsee, Räterichsbodensee and Oberaarsee (Anselmetti et al. 2007) (Fig. 1) (for details about the construction of the hydroelectric dams in the Grimsel region see Supplementary Data, Table S1).

The sediments of Lake Brienz mainly consist of finegrained (clayey silt) material that is intercalated by sandy layers. The most conspicuous deposit present in the sediment record during the investigated time period is a large subaquatic mass movement that was triggered at the Aare delta in 1996 and eroded up to $20 \mathrm{~cm}$ of sediment in the deep basin (Girardclos et al. 2007).

Table 1 Physical characteristics of Lake Brienz, Thun and Biel (Liechti 1994)

\begin{tabular}{llll}
\hline & Lake Brienz & Lake Thun & Lake Biel \\
\hline Surface area & $29.8 \mathrm{~km}^{2}$ & $48.4 \mathrm{~km}^{2}$ & $39.3 \mathrm{~km}^{2}$ \\
Surface elevation & $566 \mathrm{~m}$ a.s.l. & $558 \mathrm{~m}$ a.s.l. & $429 \mathrm{~m}$ a.s.l. \\
Maximum water depth & $261 \mathrm{~m}$ & $217 \mathrm{~m}$ & $74 \mathrm{~m}$ \\
Water volume & $5.17 \mathrm{~km}^{3}$ & $6.44 \mathrm{~km}^{3}$ & $1.24 \mathrm{~km}^{3}$ \\
Water residence time & 2.7 years & $684 \mathrm{days}^{3}$ & $58 \mathrm{days}^{2}$ \\
Catchment area & $1,140 \mathrm{~km}^{2}$ & $2,451 \mathrm{~km}^{2}$ & $8,305 \mathrm{~km}^{2}$ \\
Present trophic state & Ultra-oligotrophic & Oligo-mesotrophic & Mesotrophic \\
Lake type & Holomictic & Holomictic & Holomictic \\
Main tributaries & Aare and Lütschine & Kander and Aare & Aare \\
\hline
\end{tabular}


Lake Thun

Lake Thun is situated downstream of Lake Brienz along the Aare River course (Fig. 1). It has a surface area of $48.4 \mathrm{~km}^{2}$, a volume of $6.44 \mathrm{~km}^{3}$, a maximum depth of $217 \mathrm{~m}$ and is situated at an altitude of $558 \mathrm{~m}$ a.s.l. It is holomictic and oligo-mesotrophic and has a residence time of 684 days (Liechti 1994). Its main tributaries, the Kander and Aare rivers, are responsible for $90 \%$ of the water supply. The Aare River, which first flows through deep Lake Brienz (Fig. 1), arrives in Lake Thun almost free of coarse particles (Sturm and Matter 1972). In contrast, the Kander River, which was deviated into Lake Thun in 1714 (Fig. 1), is rich in clastic sediment load. Its deviation therefore increased the lake's sediment input by a factor of two or three between 1714 and 1840 before river-bed erosion in the Kander catchment ceased and the sedimentation rates re-adjusted to almost pre-Kander conditions (Wirth et al. 2011). At present, $85 \%$ of the sediment input to Lake Thun is supplied by the Kander River (Sturm and Matter 1972).

\section{Lake Biel}

Lake Biel is situated downstream of Lake Brienz and Lake Thun (Fig. 1). It has a surface area of $39.3 \mathrm{~km}^{2}$, a volume of $1.24 \mathrm{~km}^{3}$, a maximum depth of $74 \mathrm{~m}$ and lies at an altitude of $429 \mathrm{~m}$ a.s.l. Lake Biel is subdivided into two basins (north and south) that merge in the eastern part of the lake. It is holomictic and has changed from mesotrophic in the 1950s to eutrophic in the 1990s, with a hyper-eutrophic peak in the 1970s (Liechti 1994). The Aare River is the only tributary for the southern basin and the main water supplier of Lake Biel. It delivers $80 \%$ of the water and $90 \%$ of the allochthonous particulate matter to the lake. This sediment load largely derives from the Sarine River, a tributary to the Aare River downstream of the city of Bern (Fig. 1), as the Aare River first flows through the large decantation basins of Lake Brienz and Lake Thun acting as efficient sediment traps. The Aare River has only been flowing into Lake Biel since 1878 when the river was deviated by the Hagneck Channel into the lake in order to control devastating floods in the Seeland area (Fig. 1). The Hagneck Channel was widened in 1878 but the river continued to intensely erode the river-bed and new stabilisation constructions were built between 1887 and 1900. With the completion of these additional constructions the Hagneck hydroelectric dam was finally inaugurated in 1900 (Nast 2006). The Aare River deviation increased the catchment area of Lake Biel by a factor of four, leading to an increase in the mean water input from 55 to $240 \mathrm{~m}^{3} / \mathrm{s}$, which in turn reduced the mean residence time from 253 to 58 days (Liechti 1994). In addition to this major deviation, the regional river management program called 'Jura waters correction' also included the canalization of the naturally inflowing small rivers (Broye and Thielle) as well as a $\sim 2.5 \mathrm{~m}$ lowering of the mean lake level of Lake Biel in order to drain the surrounding wetland areas.

Reservoirs built along the Aare River

Upstream of Lake Brienz, the flow of the Aare River is affected by seven reservoirs associated with six hydropower units. $68 \%$ of the Aare River runoff is collected in this reservoir-lake system (between 862 and 2,365 m a.s.1) and is reinjected into the Aare River at an altitude of $620 \mathrm{~m}$ a.s.l (Fig. 1) (Finger et al. 2006). It has been demonstrated that the construction of hydropower dams upstream of Lake Brienz in the high-alpine area of the Grimsel Pass (Grimsel dam at $1909 \mathrm{~m}$ a.s.l built in 1929, Räterichsboden dam at 1,767 $\mathrm{m}$ a.s.1 in 1950, and Oberaar dam at 2,303 $\mathrm{m}$ a.s.1. in 1953; Fig. 1) has drastically diminished particle fluxes from the upstream glaciers to Lake Brienz. Specifically, hydropower operations have induced a shift of the particle inputs from summer to winter and have minimized peak discharges (i.e. summer high-flow events) as well as the intrusion depth of the Aare River waters in Lake Brienz (Finger et al. 2006; Wüest et al. 2007). Anselmetti et al. (2007) furthermore estimated that only $39 \mathrm{kt} / \mathrm{year}$ of finegrained $(<4 \mu \mathrm{m})$ sediment (of the total $271 \mathrm{kt} /$ year of solid particles that entered the Grimsel reservoirs on average during the last 71 years) were transported downstream to Lake Brienz, while $232 \mathrm{kt} / \mathrm{year}$ of mostly coarse particles were retained. Therefore, the total sediment input of the Aare River into Lake Brienz was reduced by two-thirds. Further details about the construction of the main dams in the Grimsel area are provided in the Supplementary Data (Table S1) of this study.

Concerning the Sarine River, which is a major tributary of the Aare River downstream of the city of Bern, the most important hydrological change over the past century was the construction of the Rossens dam that was finished in 1948. Following the completion, it took 4 months for the river to form the second largest artificial reservoir in Switzerland (200 millions $\mathrm{m}^{3}$ ) by filling Lake Gruyère (Fig. 1). Since then, the Sarine river discharge pattern has been heavily influenced by the hydroelectricity production, which maintains the downstream water discharge almost constant, excluding times of strong flood events (i.e. in 1999, 2005 and 2006). 


\section{Methodology}

Sediment coring, logging and sampling

In 2003, a 77-cm-long gravity core (BR03-10) was collected from central Lake Brienz $\left(46^{\circ} 44^{\prime} 17^{\prime \prime} \mathrm{N}, 7^{\circ} 58^{\prime} 54^{\prime \prime} \mathrm{E}\right)$ at $260 \mathrm{~m}$ water depth. This core was initially analysed to reconstruct the sediment input to Lake Brienz (Anselmetti et al. 2007).

In 2007, a 98-cm-long gravity core (THU07-06) was also collected from central Lake Thun $\left(46^{\circ} 40^{\prime} 36^{\prime \prime} \mathrm{N}\right.$, $\left.7^{\circ} 45^{\prime} 37^{\prime \prime} \mathrm{E}\right)$ at $212 \mathrm{~m}$ water depth, in an effort to evaluate changes in sediment input to Lake Thun following the rerouting of the Kander River (Wirth et al. 2011).

In 2010, a 119.5-cm-long gravity core (BIE10-3) was collected from the southern basin of Lake Biel $\left(47^{\circ} 3^{\prime} 14^{\prime \prime} \mathrm{N}\right.$, $\left.7^{\circ} 8^{\prime} 8^{\prime \prime} \mathrm{E}\right)$ at $52 \mathrm{~m}$ water depth.

After their collection, gamma-ray attenuation bulk density was measured on whole-round cores using a GEOTEK multi-sensor core logger. Afterwards, the cores were opened, photographed and sliced into $1 \mathrm{~cm}$ thick sections. These sediment samples were frozen, freeze-dried and ground into a fine homogeneous powder for chemical analysis. Water content was measured by weighing individual samples before and after freeze-drying.

\section{Radionuclide activities}

The ${ }^{137} \mathrm{Cs}$ activities of the cores from Lake Brienz, Lake Thun and Lake Biel were measured following the same procedure at Eawag (Dübendorf, Switzerland). Radionuclide activities $\left({ }^{226} \mathrm{Ra} \mathrm{t} \mathrm{t}_{1 / 2}=1,601\right.$ years; ${ }^{241} \mathrm{Am} \mathrm{t}_{1 / 2}=$ 432 years; ${ }^{137} \mathrm{Cs} \mathrm{t}_{1 / 2}=30.2$ years; ${ }^{210} \mathrm{~Pb} \mathrm{t}_{1 / 2}=22.3$ years and ${ }^{60} \mathrm{Co} \mathrm{t}_{1 / 2}=5.3$ years) were determined in $\mathrm{Bq} / \mathrm{kg}$ (dry weight) by $\gamma$-ray spectroscopy on high-purity germanium (Ge) well detectors. Geometry correction and calibration were based on standard solutions from 1 to $10 \mathrm{~mL}$, which were adapted to sample masses ranging between 0.5 and $1 \mathrm{~g}$ dry weight.

\section{Chemical treatment and ICP-MS measurements}

Around $2-3 \mathrm{mg}$ of sediment powder was completely digested using pure acids in Teflon bombs and a glass ceramic hotplate. The procedure involves three heating steps with (1) $0.5 \mathrm{ml} \mathrm{HNO}_{3}$ (suprapur ${ }^{\circledR}, 65 \%$ ), (2) a mixture of $0.3 \mathrm{ml}$ of $\mathrm{HClO}_{4}$ (suprapur ${ }^{\circledR}, 70 \%$ ) with $0.3 \mathrm{ml}$ HF (suprapur ${ }^{\circledR}, 40 \%$ ), and (3) one additional treatment with $0.3 \mathrm{ml}$ of $\mathrm{HNO}_{3}$ (suprapur ${ }^{\circledR}, 65 \%$ ). The samples were evaporated between each step of the procedure and finally diluted to $10 \mathrm{ml}$ with $1 \% \mathrm{HNO}_{3}$ solution for chemical analysis.
The concentrations of major and trace elements [including scandium $(\mathrm{Sc})$, iron $(\mathrm{Fe})$, potassium $(\mathrm{K})$, magnesium $(\mathrm{Mg})$, aluminium $(\mathrm{Al})$, titanium $(\mathrm{Ti})$, copper $(\mathrm{Cu})$, and lead $(\mathrm{Pb})$ ] were measured using a quadrupole-based inductively coupled plasma-mass spectrometer (ICP-MS, model 7700 series, Agilent). Multi-element standard solutions at different concentrations $(0,0.02,1,5,20,100$ and $200 \mathrm{ppb}$ ) were used for calibration. Standard deviations of four replicate measurements (done for each element) were below $10 \%$, and chemical blanks for the procedure were less than $5 \%$ of the sample signal. Concentrations of the different elements (given as $\mu \mathrm{g} / \mathrm{g}$ or $\mathrm{mg} / \mathrm{g}$ dry weight) were converted to element fluxes in order to correct for varying sedimentation rates when comparing the records from the three lakes. Element fluxes were calculated using the following equation:

Element flux ( $\mu \mathrm{g}$ or $\mathrm{mg} / \mathrm{cm}^{2} /$ year $)=$ Element concentration $(\mu \mathrm{g} / \mathrm{g}$ or $\mathrm{mg} / \mathrm{g}) \times$ Sedimentation rate $(\mathrm{cm} /$ year $) \times$ Density $\left(\mathrm{g} / \mathrm{cm}^{3}\right)$

In order to decipher the anthropogenic contribution to the trace-metal content, we calculated the enrichment factors $(\mathrm{EFs})$ for $\mathrm{Pb}$ concentrations using the following equation:

$\mathrm{EF}=(\mathrm{Pb}$ concentration in sample/Sc concentration in sample)/(the lowest $\mathrm{Pb} / \mathrm{Sc}$ ratio of each record)

The conservative element scandium $(\mathrm{Sc})$ was chosen because it occurs in the same concentration range as $\mathrm{Pb}$ in natural (uncontaminated) sediments and is unaffected by human activities.

\section{Results and discussion}

Age models for Lake Brienz and Lake Thun

The age models for the records of Lake Brienz (BR03-10) and Lake Thun (THU07-06) are based on core-to-core correlations with previously well-dated sediment cores from these two lakes (see Supplementary Data of this study, Figs. S1 and S2). The age-depth relation is established using the ${ }^{137} \mathrm{Cs}$ markers of 1951 (zero level), 1963 and 1986, as well as event-layer stratigraphies from flood and mass movement deposits. Details about the dating of the cores from Lake Brienz and Lake Thun are described in Anselmetti et al. (2007) and Wirth et al. (2011), respectively.

\section{Age model for Lake Biel}

The age model for the Lake Biel core (BIE10-3) is well constrained by radionuclide activity profiles of ${ }^{137} \mathrm{Cs},{ }^{60} \mathrm{Co}$, ${ }^{210} \mathrm{~Pb},{ }^{226} \mathrm{Ra}$ and ${ }^{241} \mathrm{Am}$ as well as by two additional tie points, which are the coring year (2010) and the 
completion of the Hagneck hydroelectric dam (1900; Fig. 2). Using the CFCS (constant flux constant sedimentation) model (Krishnaswamy et al. 1971), the ${ }^{210} \mathrm{~Pb}$ age model is constrained by the best-fitted $\left(R^{2}=0.91\right)$ linear slope of excess ${ }^{210} \mathrm{~Pb}$ (obtained by subtracting the ${ }^{226} \mathrm{Ra}$ activity to the ${ }^{210} \mathrm{~Pb}$ activity), which could be measured down to $63.5 \mathrm{~cm}$ core depth (i.e. 1932) and provides a mean sedimentation rate of $0.86 \mathrm{~cm} /$ year. This sedimentation rate was applied to the lower part of the core by extrapolation, resulting in an age of $1900 \mathrm{AD}$ at $94.5 \mathrm{~cm}$ core depth. This stratigraphic level coincides with conspicuous changes in lithology and magnetic susceptibility (Fig. S3), which are interpreted as decreased clastic input caused by sediment retention due the upstream Hagneck hydroelectric dam. However, as river-bed erosion by the Aare River only stabilized with the completion of the Hagneck dam in 1900 (Nast 2006), the sedimentation rate is likely enhanced for the period 1878-1900. Due to this uncertainty, the age model was not extended beyond 1900 (i.e. $94.5 \mathrm{~cm}$ ). For the period 1951-2010, the age model was verified using the ${ }^{137} \mathrm{Cs}$ activity peaks of 1986 (1985 with ${ }^{210} \mathrm{~Pb}$ age model) and $1963\left(1962\right.$ with ${ }^{210} \mathrm{~Pb}$ age model) generated by the Chernobyl accident and the global maximum radionuclide fallout due to atmospheric tests of nuclear weapons, respectively. In addition, the beginning of ${ }^{137} \mathrm{Cs}$ emission in 1951 (i.e. end of ${ }^{137} \mathrm{Cs}$ zero activity) is also used as a marker horizon (1950 with ${ }^{210} \mathrm{~Pb}$ age model, Fig. 2). Furthermore, the ${ }^{241} \mathrm{Am}$ activity peak at $41.5 \mathrm{~cm}$ depth confirms the $1963{ }^{137} \mathrm{Cs}$ peak due to atmospheric fallout. Overall, the ${ }^{210} \mathrm{~Pb}$ - and ${ }^{137} \mathrm{Cs}$ age models differ only by about 1 year, which is likely due to measurement/ sampling uncertainties and model used.

Impact of manmade reservoirs on element fluxes

Instrumental precipitation records from different monitoring stations in Central Switzerland (Begert et al. 2005) present strikingly similar variations but nonetheless indicate that more precipitation falls in mountainous areas (Engelberg and Chateau d'Oex: 1,200-1,700 mm/year) than on the Swiss Plateau (Bern: $\sim 1,000 \mathrm{~mm} /$ year) (Fig. 4). This pattern is due to the altitude effect of precipitation $(\sim 0.7 \mathrm{~mm} / \mathrm{m}$ in altitude in the northern part of the Alps; Schädler and Weingartner 2002), which is strongly influencing the distribution of mean annual precipitation in Switzerland (Fig. 1). Despite considerable seasonal and topographic effects, the analysis of meteorological data sets has shown that the annual precipitation amounts in Switzerland during the twentieth century slightly increased in most sub-regions and for all seasons with the exception of summer (Widmann and Schär 1997). Regarding the here used meteorological stations, a slight long-term increase in total annual precipitation is observed for the station of Chateau d'Oex, while the two other precipitation series (Engelberg and Bern) remain relatively constant over the last century (Fig. 4).

The discharge records of the Lütschine River (number 5 in Fig. 4), which is an Alpine torrent largely unaffected by human activities, and of the Aare River in Thun and Bern (number 3 and 2 in Fig. 4) both show a good consistency with the temporal trends of the precipitations series (FOEN 2010). However, these patterns strongly contrast to the discharge of the Aare River measured in the upper part of its watershed (gauging station in Brienzwiler, number 4 in Fig. 4), for which a decreasing trend is observed between 1930 and 1970, occurring synchronously with the construction of the hydropower reservoirs upstream of Lake Brienz (number 12 in Fig. 4). Synchronously with the extensive construction of dams in Switzerland, abrupt drops are also recorded in the discharge pattern of the Sarine River in Fribourg (number 1 in Fig. 4). Thereby, the most conspicuous decrease in the Sarine River discharge occurred after the construction of the Rossens dam in 1948 (number 13 in Fig. 4). Furthermore, the intense contemporaneous economic development as well as the availability of infrastructures for water storage and water delivery in these areas certainly fostered water withdrawal for human uses (agriculture, industry and municipal use). This may be especially important in the Rossens area and in the vicinity of Lake Biel, where agriculture is more important than in the upstream course of the Aare River.

It has recently been demonstrated that the river-transported sediment load into Lake Brienz is strongly dependent on the peaks in the discharge regime and that hydropower damming has drastically diminished particle fluxes and minimized (short-term) peak discharges (Finger et al. 2006; Bonalumi et al. 2011). Hence, hydropower operations in the Grimsel area significantly modified suspended particle loads (and seasonal water discharge) to Lake Brienz (Finger et al. 2006). An additional study conducted on the sedimentation of the fine particle fraction from the water column in the two high-altitude reservoirs Oberaarsee and Grimselsee (Fig. 1) that have been used for pump-storage operations since 1980 demonstrated that pump-storage operations have not only strongly modified the downstream but also the overall sedimentation processes (Bonalumi et al. 2011). Before the construction of the reservoirs particle input to Lake Biel mainly happened during snowmelt in late spring/early summer and during extreme runoff events in summer (Finger et al. 2006). However, upstream hydropower operations have shifted the main part of the sediment input from summer to winter.

The fluxes of terrigenous elements $(\mathrm{Sc}, \mathrm{Ti}, \mathrm{Mg}, \mathrm{Fe}, \mathrm{K}$ and $\mathrm{Al}$ ) transported to the coring sites of Lake Brienz, Lake Thun, and Lake Biel do not follow the precipitation pattern of the area, strongly suggesting a catchment scale impact of 


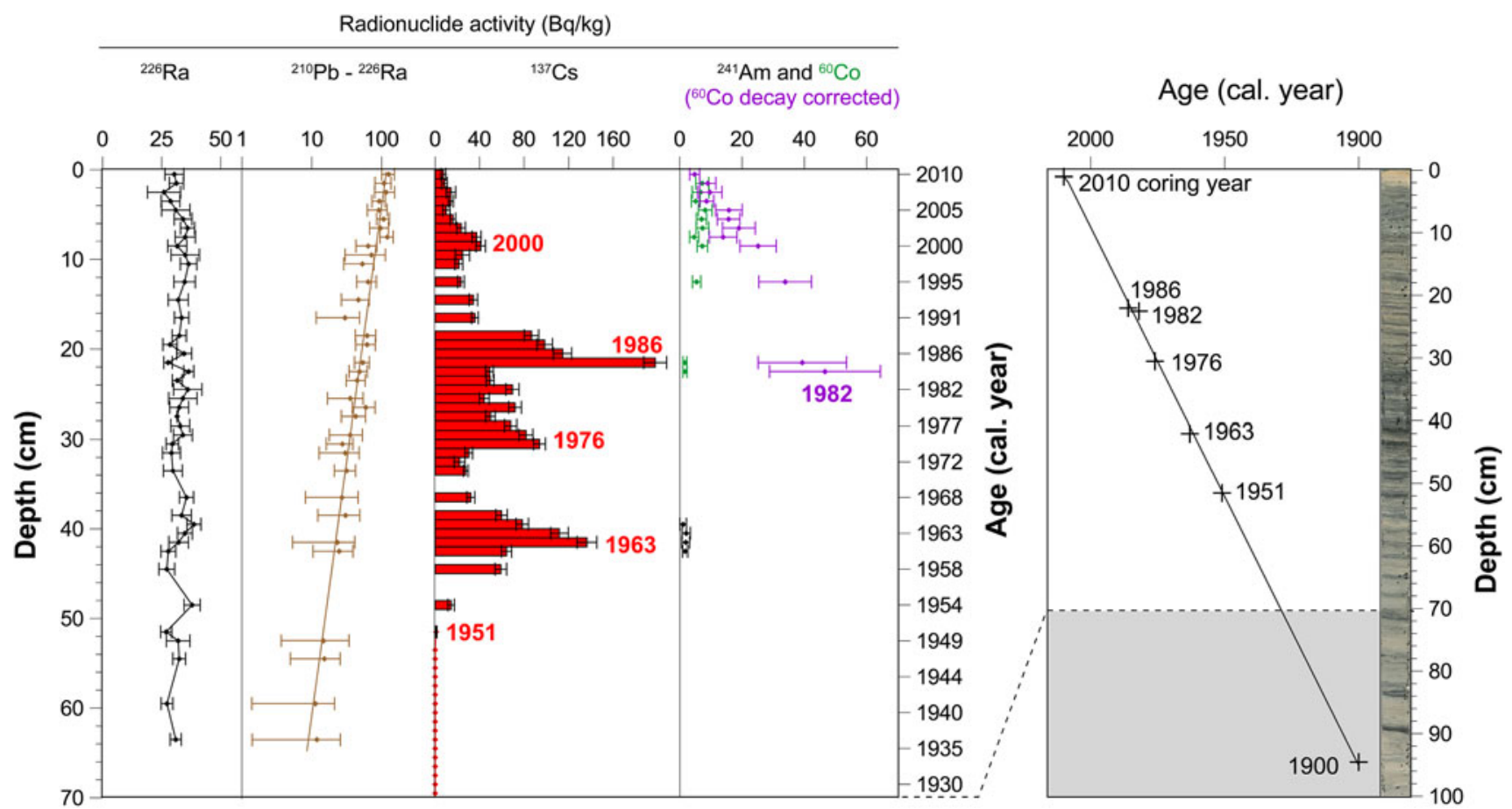

Fig. 2 Left Radionuclide activities of the Lake Biel sediment core (BIE10-3). Excess ${ }^{210} \mathrm{~Pb}$ activity $\left({ }^{226} \mathrm{Ra}\right.$ activity subtracted) with horizontal error bars expressed as $95 \%$ confidence levels and the regression line $\left(\mathrm{R}^{2}=0.91\right)$ showing a constant sedimentation rate $\left(0.86 \mathrm{~cm} /\right.$ year) down to $63.5 \mathrm{~cm}$ (1937). Activities of ${ }^{137} \mathrm{Cs},{ }^{241} \mathrm{Am}$, ${ }^{60} \mathrm{Co}$ and ${ }^{60} \mathrm{Co}$ were decay corrected with peak emission sources (the

the numerous water reservoirs constructed in the upstream part of the catchment area since about 1930 (Fig. 3). For example, the Ti flux record of Lake Biel shows a strong decrease from values ranging around $4 \mathrm{mg} / \mathrm{cm}^{2} /$ year to values around $3 \mathrm{mg} / \mathrm{cm}^{2} /$ year after ca. 1950 (Fig. 4), suggesting a reduction of the terrigenous flux of $\sim 25 \%$ during the second part of the twentieth century. A similar reduction in the transportation of $\mathrm{Ti}$ is also observed in Lake Brienz between 1950 and 1970 (Fig. 4). Although an additional effect of artificial water withdrawal (especially for agriculture) cannot be ruled out, our sedimentary records of terrigenous material fluxes from Lake Biel and Lake Brienz indicate that the shift of the main runoff from summer to winter due to the hydropower damming combined to the retention of suspended particles in the reservoirs (see previous paragraph), significantly reduced the riverine sediment load of the Aare River. A similar reduction in the recent transport of terrigenous elements has been reported in other large and deep peri-alpine lakes. Before the beginning of massive land-use changes in the late-nineteenth century, the crustal element concentrations in the sediments of Lake Lucerne that are associated with the silicate-clay fraction were primarily influenced by climate-induced hydrological changes (Thevenon et al. 2012). By contrast, the lower $\mathrm{Ti}$ input also measured in the data below the detection limit for ${ }^{60} \mathrm{Co}$ are not represented). Right Age-depth model of the sediment record based on excess ${ }^{210} \mathrm{~Pb}$ showing the chronological markers derived from radionuclides activities (left part). The coring year (2010) and the Hagneck hydroelectric dam inauguration year (1900) have been added (Fig. S3 for details on core interpretation)

deepest part of Lake Geneva during the twentieth century (Fig. S5; details in Thevenon et al. 2011a) indicates reduced terrigenous sediment transport due to lower summer Rhone River flows and increased sediment entrapment in the numerous reservoirs built along the upstream Rhone River course (Loizeau et al. 1997). These studies demonstrate that the extensive construction of water reservoirs during the middle of the twentieth century in Switzerland significantly reduced terrigenous fluxes to major alpine rivers and to the large and deep peri-alpine lakes.

The three times higher flux of terrigenous elements into upstream Lake Brienz compared to downstream Lake Thun and Lake Biel can be easily explained by more intense weathering and hydrological processes in its glaciated mountainous catchment (resulting in a higher flux of terrigenous sediment transported by the Lütschine and Aare rivers) and also by the fact that Lake Brienz constitutes the first large sediment sink of the Aare River (Girardclos et al. 2007) (Fig. 3 and S5).

Importantly, turbidites related to large mass movements in Lake Brienz (details in Girardclos et al. 2007) were not reported in Figs. 3 and 4. Apparently, such events strongly enhance elemental fluxes because of a sudden increase in sedimentation rate and terrigenous element input (Fig. S5). However, these mass movement deposits represent 


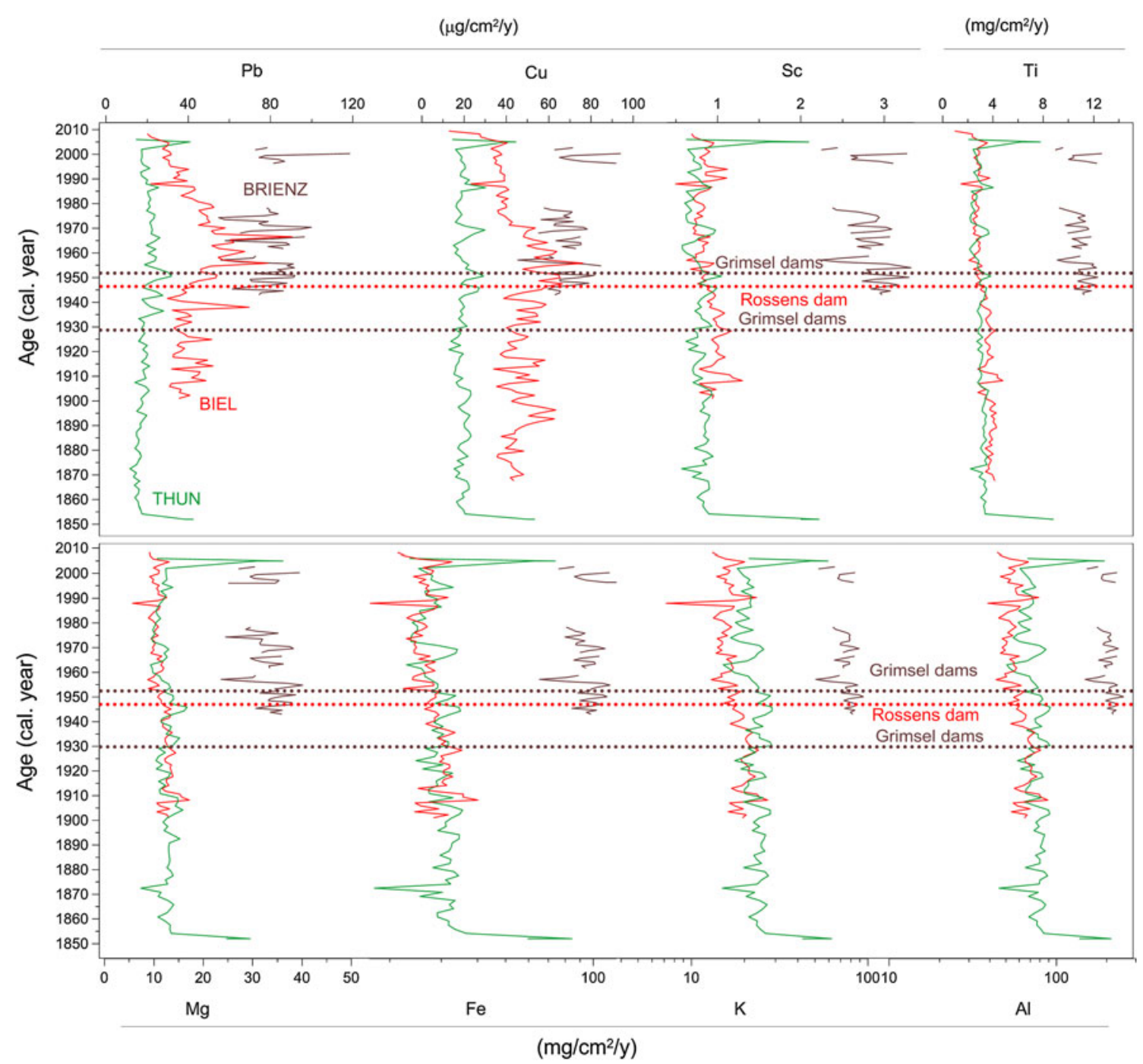

Fig. 3 Trace element fluxes of Lake Biel, Lake Thun and Lake Brienz as a function of age (calendar years). A large turbidite layer deposited in 1996 interrupts the sedimentary record and generates a

material redeposited within the lake basin and therefore do not reflect riverine sediment input. In contrast, two small turbidites triggered by flood events detected in the lower and upper parts of the sediment core of Lake Thun reflect real short-term increases of elements fluxes (Figs. 3 and 4) (see Wirth et al. 2011 for details about these turbidites).

Element fluxes for tracking anthropogenic pollution

In contrast to the natural elemental fluxes, differences among the three lakes are observed in the occurrence of anthropogenically-derived elements. Indeed, $\mathrm{Pb}$ and $\mathrm{Cu}$ fluxes into Lake Biel during the middle of the 20th century strongly differ from the above-presented pattern of the natural trace elements (Fig. 3 and S4). This is explained by a higher anthropogenic contribution to heavy metal influx in the downstream reaches of the Aare River (EF $\mathrm{Pb}$, hiatus of $17 \pm 1$ years in core BR03-10 (details in Girardclos et al. 2007). Note the log scale for Fe, $\mathrm{K}$ and $\mathrm{Al}$

Fig. 4). The natural flux of $\mathrm{Pb}$ into Lake Brienz $(80 \mu \mathrm{g} /$ $\mathrm{cm}^{2} /$ year) is two times higher than to Lake Thun (40 $\mu \mathrm{g} / \mathrm{cm}^{2} /$ year) and four times larger than to Lake Biel (20 $\mu \mathrm{g} / \mathrm{cm}^{2} /$ year) (Fig. 3). The Lake Brienz record does not give evidence for anthropogenic lead deposition, whereas a moderate enrichment of $\mathrm{Pb}(>1.5)$ is detected in Lake Thun. In contrast, the Lake Biel sediment record is characterized by a strong enrichment of $\mathrm{Pb}$, which is similar as in the deepest part of Lake Geneva following the industrial revolution (Thevenon et al. 2011a; Fig. 4). One must note that the lowest values found in the records might still include some amounts of human-induced trace metals because anthropogenic trace-metal pollution in the large Swiss lakes started to increase following the industrial revolution in Europe in ca. 1850 (Thevenon et al. 2011a, 2011b; Thevenon and Poté 2012). However, as a result of the very high dilution by the Rhône River (mean discharge 


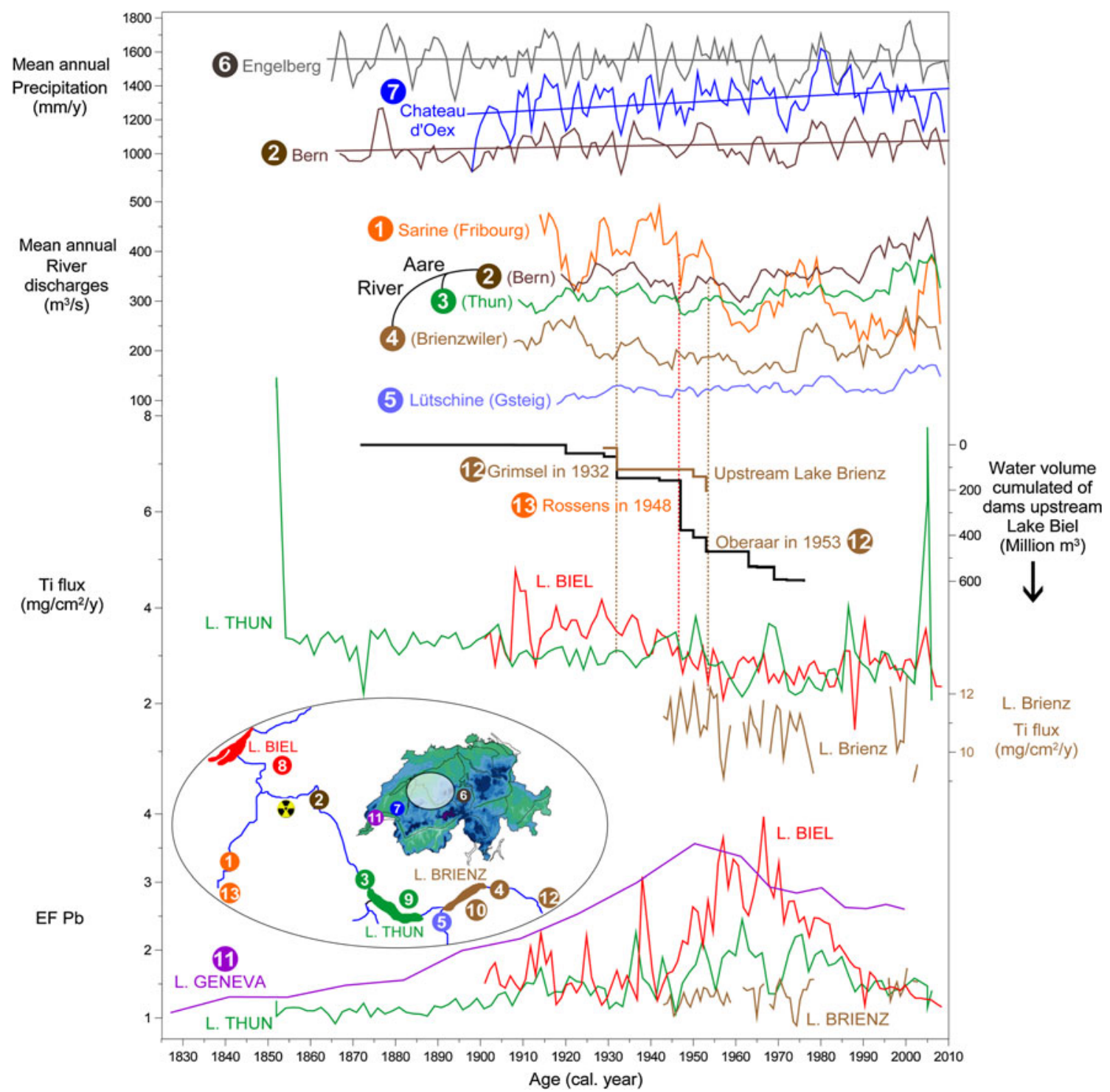

Fig. 4 Instrumental records of annual precipitation as 3 year running average (numbers 2, 6 and 7) (Begert et al. 2005) and of annual river discharge as 5 year running average (FOEN, 2010) with locations of gauging stations ( 1 to 5 ) reported on the inserted map. Beneath follow

of $654 \mathrm{~m}^{3} / \mathrm{s}$ over the last 56 years; FOEN 2010) for Lake Geneva and by the Aare River (mean discharge of $717 \mathrm{~m}^{3} / \mathrm{s}$ over the last 27 years; FOEN 2010) for Lake Biel, EF Pb remains relatively low in both lake sediments shortly after the industrial revolution whereas maximum values are reached between 1950 and $1970(\mathrm{EF} \mathrm{Pb}>3$; Fig. 4). Since 1970, anthropogenic $\mathrm{Pb}$ has decreased to the level of the late $19^{\text {th }}$ century in Lake Thun and Lake Biel (Fig. 4). Interestingly, this long-term reduction in aquatic $\mathrm{Pb}$ pollution started about 15 years before the introduction of unleaded gasoline and synchronously with the large peri-alpine Lake Lucerne and Lake Geneva. As demonstrated by the isotope systematic of $\mathrm{Pb}$, which was used to determine the origin of $\mathrm{Pb}$ (Monna et al. 1999; Thevenon the dates of dam constructions upstream of Lake Biel (12 and 13) as well as Ti fluxes and $\mathrm{Pb}$ enrichment factors (EF Pb) for Lake Biel (8), Lake Thun (9) and Lake Brienz (10). EF Pb from Lake Geneva (11) is reported for comparison

et al. 2011a), the reduction in $\mathrm{Pb}$ input into these lakes primarily resulted from an increase in the number of sewage plants and thus the improved treatment of industrial (and domestic) wastewaters in the largest cities of Switzerland.

Although the maximum anthropogenic $\mathrm{Pb}$ input to Lake Biel occurred between 1950 and 1970, i.e. during the time period when leaded gasoline was used in Switzerland (between 1947 and 1985), the striking similarity between the $\mathrm{Pb}$ and $\mathrm{Cu}$ records (Fig. 3) suggests the same origin and transport pathway for these two elements rather than the use of leaded gasoline as dominant source of lead in Lake Biel during this period. This result is consistent with (1) the sedimentary records from other low- and high-altitude lakes 
recently studied in Switzerland, indicating a similar pattern of $\mathrm{Pb}$ enrichment and of other anthropogenic metals (e.g. Hg, $\mathrm{Cu}, \mathrm{Zn}, \mathrm{Mn}$ ) (Thevenon et al. 2011a, 2011b, 2013), and with (2) peat bog records of lead pollution in Switzerland, indicating a maximum extent of atmospheric contamination (primarily supplied by coal burning) in Europe in 1954, which predates the maximum impact of $\mathrm{Pb}$ emissions from the use of leaded gasoline (Shotyk et al. 2002). Similarly to the large and deep peri-alpine Lake Constance (NE Switzerland), the apparent absence of a significant gasoline $\mathrm{Pb}$ peak in Lake Biel (and in the other peri-alpine lakes mentioned before) during the 1970s and 1980s could therefore be due to a compensation of the enhanced aeolian $\mathrm{Pb}$ flux (gasoline $\mathrm{Pb}$ ) by a much lower release of fluvial $\mathrm{Pb}$ (building of sewage plants) after 1960 (Kober et al. 1999). The sedimentary records from the large peri-alpine lakes therefore exclude alkyl-lead added to petrol as the major source of (aquatic) $\mathrm{Pb}$ pollution, and rather point at an overall metal pollution due to increasing urbanization and industrialization processes (waste incineration, metal smelting processes and fossil fuel combustion) until the 1970s. Increased emission controls, becoming effective in the late 1970s, reduced atmospheric (metal) pollution and implemented wastewater treatment plants to reduce industrial (and domestic) aquatic metal pollution.

\section{Evidence for contamination by the nuclear power plant}

Additionally to the three ${ }^{137} \mathrm{Cs}$ markers generally used for dating (1951, 1963 and 1986) European sediment records, the Lake Biel sediment core (BIE10-3) revealed two additional ${ }^{137} \mathrm{Cs}$ activity peaks at $8.5(41 \mathrm{~Bq} / \mathrm{kg})$ and $30.5 \mathrm{~cm}$ core depth $(94 \mathrm{~Bq} / \mathrm{kg}$ ) (Fig. 2). On the basis of the ${ }^{210} \mathrm{~Pb}$ age model, these peaks are dated to 2000 and 1975. The peak dated to 1975 has been reported in a previous study and detected in several Lake Biel sediment cores, of which the nearest is only $300 \mathrm{~m}$ away from our site (Albrecht et al. 1998). This increased ${ }^{137} \mathrm{Cs}$ activity was caused by higher radionuclide discharges of the upstream Mühleberg NPP due to the use of low-quality fuel rods between 1976 and 1978 (Albrecht et al. 1998). In addition, a small ${ }^{60} \mathrm{Co}$ activity peak detected at $22.5 \mathrm{~cm}$ core depth is dated to 1984 on the basis of our ${ }^{210} \mathrm{~Pb}$ activity age model (Fig. 2). Albrecht et al. (1998) suggested that this peak was related to higher wastewater discharges from the Mühleberg NPP documented in August of 1982. The age difference of 1-2 years between the age model and the date of the known nuclear events lies within the error range of our age model (see next paragraph). Our results therefore confirm the previous identification of increased radionuclide discharge by the Mühleberg NPP in $1976\left({ }^{137} \mathrm{Cs}\right)$ and $1982\left({ }^{60} \mathrm{Co}\right)$. However, regarding the 1982 event, our data is not as definite as Albrecht et al. $(1998,1999)$ because
${ }^{60} \mathrm{Co}$, which was the only released radionuclide during this event, shows at present only slightly elevated activity in our Lake Biel record.

In the upper part of our Lake Biel sediment core, a small ${ }^{137} \mathrm{Cs}$ activity peak dated to 2000 is for the first time revealed by this study (Fig. 1). The ${ }^{60} \mathrm{Co}$ as well as the ${ }^{210} \mathrm{~Pb}$ in excess (obtained after subtracting the ${ }^{226} \mathrm{Ra}$ activity to the total ${ }^{210} \mathrm{~Pb}$ activity) profiles demonstrate that this ${ }^{137} \mathrm{Cs}$ activity peak was not caused by other processes, such as reworking of sediment containing Chernobyllinked activity or changes in sedimentation rates which would appear in the ${ }^{210} \mathrm{~Pb}$ in excess profile. Therefore, this ${ }^{137} \mathrm{Cs}$ activity peak that is not accompanied by a coeval ${ }^{60} \mathrm{Co}$ peak can be explained by two possible causes: (1) only ${ }^{137} \mathrm{Cs}$ radionuclides were released to the environment, or (2) the ${ }^{137} \mathrm{Cs}$ was better scavenged by the minerogenic fraction than ${ }^{60} \mathrm{Co}$. Indeed, only 30 to $55 \%$ of the discharged ${ }^{60} \mathrm{Co}$ is transferred to Lake Biel sediments and the scavenging efficiency of ${ }^{60} \mathrm{Co}$ is higher during the winter period than during summer, in spite of higher particle fluxes during summer (Albrecht et al. 1999). Thus, the found moderate ${ }^{137} \mathrm{Cs}$ activity peak likely points to an additional and so far undetected release of liquid radionuclides from the Mühleberg NPP to the Aare River in the year $2000 \pm 2$. This discharge event could coincide with an event reported at the Mühleberg NPP on the 6th of June 1998, when an accidental opening of a steam-relief valve led to an emergency shutdown of the reactor (Prêtre 1999). Yet, the Swiss government monitors radionuclide activity in the air and water near the Mühleberg NPP, but registered values for 1998 are similar to those of previous years and lie all below $3 \%$ of the legal limit (Prêtre 1999). Similarly, the automatic dose rate monitoring network (MADUK), which consists of four subsidiary networks located within a radius of $6 \mathrm{~km}$ of each Swiss nuclear power plant and which has been recording since 1995 the local dose rate of Mühleberg NPP every $10 \mathrm{~min}$ as a function of natural levels of radiation, does not reveal any conspicuous values since data was not published for most of 1998 because of technical problems (Baur and Schug 2003).

In any case, considering that (1) Lake Biel sediments most probably only recorded a small portion of the discharged radionuclides (Albrecht et al. 1999), that (2) $70 \%$ of the drinking water of the city of Biel (57,000 inhabitants) originates from Lake Biel, and that (3) the Aare River is a main tributary to the High Rhine River, the sedimentary profiles of radionuclides from Lake Biel raise serious concerns about possible large-scale contamination of drinking water and groundwater systems by the hydrological dispersion of radioactive materials over long distances. Indeed, NPPs are generally built at the shores of lakes, rivers or oceans to provide large quantities of cooling water and, similarly to the sediment records from Lake Biel, previous studies from the 
Rhône River also demonstrated that radionuclides released by the nuclear industry are dispersed through surface waters over long distances (Martin and Thomas 1990; Provansal et al. 2012; Ferrand et al. 2012; Albrecht et al. 1998).

\section{Conclusion}

This study highlights natural variations in terrigenous fluxes (controlled by factors such as catchment relief, denudation rate, river discharge volumes) and anthropogenic effects (building of dams and river regulation) on the transport of suspended sediment loads from the alpine environment to the peri-alpine foreland, i.e. to peri-alpine lacustrine basins. The terrigenous fluxes reconstructed at our studied sites indicate that sediment-transfer processes at the catchment scale are significantly altered by artificial hydropower reservoir lakes located in the upper reaches of the catchment. Our research demonstrates that the construction of dams in Switzerland significantly reduced trace element fluxes to downstream areas over the last $\sim 50$ years. In fact, terrigenous particle fluxes have been significantly reduced by the construction of reservoir dams in the Swiss Alps. This result reveals the importance of considering human-induced effects when reconstructing past climate variations using historical discharge data and lacustrine sedimentary archives or when estimating modern weathering rates based on the abundance of riverine suspended mineral particles. The fluxes of anthropogenicallyproduced trace elements $(\mathrm{Cu}$ and $\mathrm{Pb})$ indicate that metal pollution significantly increases in the lower, less mountainous, reaches of the Aare River by revealing the maximum pollution between $\sim 1940$ and 1970 in the sediments of Lake Biel. In addition, we found that the alkyllead added to gasoline was not the dominant (aquatic) source of lead input to the studied large peri-alpine lakes. Last but not least, the radionuclide dating of the sediment core from Lake Biel evidences the deposition of radionuclides emitted by the upstream nuclear reactor of Mühleberg (distance $15 \mathrm{~km}$ ) during the late 20th century.

Acknowledgments This research was funded by Swiss National Science Foundation (SNSF) project n. 200021-121666 and a SNSF Ambizione fellowship grant (PZ00P2 136899). Initial research on cores from Lake Thun and Lake Brienz was funded by SNSF project 620-066113 when S.G. was at the Geological Institute of ETH Zurich (Switzerland) under the direction of Flavio Anselmetti. We are grateful to Christine Guido-Bruno for her help with sediment sampling and laboratory analyses, to Katrina Kremer for help with MSCL analyses, and to Adrian Gilli for access to the ETH Zurich Limnogeology Laboratory. We thank the Federal Office for the Environment (FOEN) in Ittingen for hydrological data. We also thank: Flavio Anselmetti and Alois Zwyssig from Eawag for the boat, Philippe Arpagaus from Institut Forel for equipment transport, Mathias Rüedi and Manuel Tièche from BASPO Ipsach (Swiss Federal Sport Office) for harbor logistics, as well as Katrina Kremer, Pauline Masset and
Aymeric Le Cotonnec from the University of Geneva for sediment coring on Lake Biel.

Open Access This article is distributed under the terms of the Creative Commons Attribution License which permits any use, distribution, and reproduction in any medium, provided the original author(s) and the source are credited.

\section{References}

Albrecht A, Reiser R, Lueck A, Stoll JMA, Giger W (1998) Radiocesium dating of sediments from lakes and reservoirs of different hydrological regimes. Environ Sci Technol 32(13): $1882-1887$

Albrecht A, Goudsmit G, Zeh M (1999) Importance of lacustrine physical factors for the distribution of anthropogenic ${ }^{60} \mathrm{Co}$ in Lake Biel. Limnol Oceanogr 44:196-206

Anselmetti FS, Bühler R, Finger D, Girardclos S, Lancini A, Rellstab C, Sturm M (2007) Effects of Alpine hydropower dams on particle transport and lacustrine sedimentation. Aquat Sci 69:179-198

Arnaud F, Revel-Rolland M, Bosch D, Winiarski T, Desmet M, Tribovillard N et al (2004) A 300 year history of lead contamination in northern French Alps reconstructed from distant lake sediment records. J Environ Monit 6:448-456

Arnaud F, Revel M, Chapron E, Desmet M, Tribovillard N (2005) 7200 years of Rhone river flooding activity in Lake Le Bourget, France: a high-resolution sediment record of NW Alps hydrology. The Holocene 15:420-428

Baur W, Schug I (2003) Jahresbericht 2002 zum System MADUK (HSK-AN-4622). Federal Office of Energy, Villigen, Switzerland, $\mathrm{p} 11$

Begert M, Schlegel T, Kirchhofer W (2005) Homogeneous temperature and precipitation series of Switzerland from 1864 to 2000. Int J Climatol 25:65-80

Bezinge A, Clark MJ, Gurnell AM, Warburton J (1989) The management of sediment transported by glacial melt-water streams and its significance for the estimation of sediment yield. Ann Glaciol 13:1-5

Bonalumi M, Anselmetti FS, Kaegi R, Wüest A (2011) Particle dynamics in high-Alpine proglacial reservoirs modified by pumped-storage operation. Water Resour Res 47:W09523

Chapron E, Arnaud F, Noel H, Revel M, Desmet M, Perdereau L (2005) Rhone river flood deposits in Lake Le Bourget: a proxy for holocene environmental changes in the NW Alps, France. Boreas 34:404-416

Eades LJ, Farmer JG, MacKenzie AB, Kirida A, Bailey-Watts AE (2002) Stable lead isotopic characterization of the historical record of environmental lead contamination in dated freshwater lake sediment cores from northern and central Scotland. Sci Total Environ 292:55-67

Ferrand E, Eyrolle F, Radakovitch O, Provansal M, Dufour S, Vella C, Raccasi G, Gurriaran R (2012) Historical levels of heavy metals and artificial radionuclides reconstructed from overbank sediment records in lower Rhône River (South-East France). Geochemica Cosmochimica Acta 82:163-182

Finger D, Schmid M, Wüest A (2006) Effects of upstream hydropower operation on riverine particle transport and turbidity in downstream lakes. Water Resour Res 42:W08429

FOEN (2010) Federal office for the environment, hydrology division, www.bafu.admin.ch

Gaillardet J, Dupre B, Louvat P, Allegre CJ (1999) Global silicate weathering and $\mathrm{CO}_{2}$ consumption rates deduced from the chemistry of large rivers. Chem Geol 159(1-4):3-30 
Girardclos S, Fiore J, Rachoud-Schneider A-M, Baster I, Wildi W (2005) Petit-Lac (western Lake Geneva) environment and climate history from deglaciation to the present: a synthesis. Boreas 34:417-433

Girardclos S, Schmidt OT, Sturm M, Ariztegui D, Pugin A, Anselmetti FS (2007) The 1996 AD delta collapse and large turbidite in Lake Brienz. Mar Geol 24:137-154

Hinderer M (2001) Late quaternary denudation of the Alps, valley and lake fillings and modern river loads. Geochimica Acta 14:231-263

Ivy-Ochs S, Schafer J, Kubik PW et al (2004) Deglaciation timing on the northern Alpine foreland (Switzerland). Eclogae Geol Helv 97:47-55

Kober B, Wessels M, Bollhöfer A, Mangini A (1999) Pb isotopes in sediments of Lake Constance, central Europe constrain the heavy metal pathways and the pollution history of the catchment, the lake and the regional atmosphere. Geochim Cosmochim Acta 63:1293-1303

Krishnaswamy S, Lal D, Martin JM, Meybeck M (1971) Geochronology of lake sediments. Earth Planet Sci Lett 11:407-414

Liechti P (1994) L'état des lacs en Suisse. Cahier de l'Environnement, 237. Office Fédéral de l'Environnement, des Forêts et du Paysage (OFEFP), Berne , Switzerland, p 159

Loizeau J-L, Dominik J (2000) Evolution of the upper Rhone River discharge and suspended sediment load during the last 80 years and some implications for Lake Geneva. Aquat Sci 62:54-67

Loizeau J-L, Dominik PY, Luzzi T, Vernet J-P (1997) Sediment core correlation and mapping of sediment accumulation rates in Lake Geneva (Switzerland, France) using volume magnetic susceptibility. J Great Lakes Res 23(4):391-402

Martin JM, Thomas AJ (1990) Origins, concentrations and distributions of artificial radionuclides discharged by the Rhône River to the Mediterranean Sea. J Environ Radioact 11:105-139

MeteoSwiss (2012) Bulletin climatologique avril 2012, Genève

Millot R, Gaillardet J, Dupré B, Allègre CJ (2003) Northern latitude chemical weathering rates: clues from the Mackenzie River basin, Canada. Geochimica Cosmochimica Acta 67(7):1305-1329

Monna F, Dominik J, Loizeau J-L, Pardos M, Arpagaus P (1999) Origin and evolution of $\mathrm{Pb}$ in sediments of Lake Geneva (Switzerland-France). Environ Sci Technol 33(17):2850-2857

Mundschenk H (1992) Study of the long-range effects of radioactive effluents from nuclear power plants in the Rhine River using ${ }^{58} \mathrm{Co}$ and ${ }^{60} \mathrm{Co}$ as tracers. J Environ Radioact 15:51-68

Mundschenk H (1996) Occurrence and behaviour of radionuclides in the Moselle River Part IV: deposition of radioactive particulate matter in high-sedimentation areas. J Environ Radioact 32: $193-212$

Nast M (2006) Terre du lac: L'histoire de la correction des eaux du Jura. Verein Schlossmuseum Nidau, Nidau (Switzerland), p 192

Pokrovsky OS, Viers J, Shirokova LS, Shevchenko VP, Filipov AS, Dupré B (2010) Dissolved, suspended, and colloidal fluxes of organic carbon, major and trace elements in the Severnaya Dvina River and its tributary. Chem Geol 273(1-2):136-149

Prêtre S (1999) HSK Jahresbericht 1998 über die nukleare Sicherheit und den Strahlenschutz in den schweizerischen Kernanlagen. HSK (Hauptabteilung für die Sicherheit der Kernanlagen/Swiss Federal Nuclear Safety Inspectorate), Würenlingen, p 130. static.ensi.ch/1314195772/jabe98.pdf

Provansal M, Ferrand E, Eyrolle F, Raccasi G, Monaco M, Guriarran R (2012) Spatial variability in sedimentation rates and artificial radionuclide storage in alluvial banks of the lower Rhône River. Aquat Sci 74(4):735-750

Schädler B, Weingartner R (2002) Ein detaillierter hydrologischer Blick auf die Wasserressourcen der Schweiz-Niederschlagskartierung im Gebirge als Herausforderung. Wasser-EnergieLuft 94(7/8):189-197
Shotyk W, Weiss D, Appleby PG, Cheburkin AK, Frei R, Gloor M, Kramers JD, Reese S, van der Knaap WO (1998) History of atmospheric lead deposition since $12,370{ }^{14} \mathrm{C}$ yr BP recorded in a peat bog profile, Jura Mountains, Switzerland. Science 281:1635-1640

Shotyk W, Weiss D, Heisterkamp M, Cheburkin AK, Adams FC (2002) A new peat bog record of atmospheric lead pollution in Switzerland: $\mathrm{Pb}$ concentrations, enrichment factors, isotopic composition and organolead species. Environ Sci Technol 36:3893-3900

Sturm M, Matter A (1972) Sedimente und Sedimentationsvorgänge im Thunersee. Eclogae Geol Helv 65(3):563-590

Syvitski JPM, Vörösmarty C, Kettner AJ, Green P (2005) Impact of humans on the flux of terrestrial sediment to the global coastal ocean. Science 308:376-380

Thevenon F, Poté J (2012) Water pollution history of Switzerland recorded by sediments of the large and deep perialpine lakes Lucerne and Geneva. Water Air Soil Pollut 223:6157-6169

Thevenon F, Graham ND, Chiaradia M, Arpagaus P, Wildi W, Poté J (2011a) Local to regional scale industrial heavy metal pollution recorded in sediments of large freshwater lakes in Central Europe (lakes Geneva and Lucerne) over the last centuries. Sci Total Environ 412-413:239-247

Thevenon F, Guédron S, Chiaradia M, Loizeau JL, Poté J (2011b) (Pre-) historic changes in natural and anthropogenic heavy metals deposition inferred from two contrasting Swiss Alpine lakes. Quatern Sci Rev 30(1-2):224-233

Thevenon F, Adatte T, Poté J, Spangenberg JE (2012) Recent humaninduced trophic change in the large and deep perialpine Lake Lucerne (Switzerland) compared to historical geochemical variations. Palaeogeogr Palaeoclimatol Palaeoecol 363-364:37-47

Thevenon F, de Alencastro LF, Loizeau JL, Adatte T, Grandjean D, Poté J (2013) A high-resolution historical sediment record of nutrients, trace elements and organochlorines (DDT and PCB) deposition in a drinking water reservoir (Lake Brêt, Switzerland) points at local and regional pollutant sources. Chemosphere 90:2444-2452

Vörösmarty CJ, Meybeck M, Fekete B, Sharma K, Gree P, Syvitski JPM (2003) Anthropogenic sediment retention: major global impact from registered river impoundments. Global Planet Change 39:169-190

Walling DE, Owens PN, Leeks GJL (1998) The role of channel and floodplain storage in the suspended sediment budget of the River Ouse, Yorkshire, UK. Geomorphology 22:225-242

Wessels M (1998) Natural environmental changes indicated by Late Glacial and Holocene sediments from Lake Constance, Germany. Palaeogeogr Palaeoclimatol Palaeoecol 140:421-432

Wetter O, Pfister C, Weingartner R, Luterbacher J, Reist T, Trösch J (2011) The largest floods in the High Rhine basin since 1268 assessed from documentary and instrumental evidence. Hydrol Sci J 56:733-758

Widmann ML, Schär C (1997) A principal component and long-term trend analysis of daily precipitation in Switzerland. Int $\mathbf{J}$ Climatol 17(12):1333-1356

Wirth SB, Girardclos S, Rellstab C, Anselmetti FS (2011) The sedimentary response to a pioneer geo-engineering project: tracking the Kander River deviation in the sediments of Lake Thun (Switzerland). Sedimentology 58(7):1737-1761

Wittmann H, von Blanckenburg F, Kruesmann T, Norton KP, Kubik PW (2007) Relation between rock uplift and denudation from cosmogenic nuclides in river sediment in the Central Alps of Switzerland. J Geophys Res 112:F04010

Wüest A, Zeh M, Ackermann JD (2007) Lake Brienz project: an interdisciplinary catchment-to-lake study. Aquat Sci 69:173-178

Yang SL, Zhang J, Zhu J, Smith JP, Dai SB, Gao A, Li P (2005) Impact of dams on Yangtze River sediment supply to the sea and delta intertidal wetland response. J Geophys Res 110:F03006 